\title{
Leptin gene polymorphism of Ongole Grade cattle based on single nucleotide polymorphism
}

\author{
N. Hilmia*, D. Rahmat and D. Dudi \\ Department of Animal Production, Faculty of Animal Husbandry, Universitas Padjadjaran, \\ Jl. Raya Bandung Sumedang Km 21 Jatinangor Sumedang - Indonesia \\ *CorrespondingE-mail: nena.hilmia@unpad.ac.id
}

Received April 26, 2018; Accepted July 12, 2018

\begin{abstract}
ABSTRAK
Mutasi titik pada sekuen nukleotida gen leptin exon 2 yang mengubah pengodean asam amino dari Arginin menjadi Sistein diduga dapat mengubah fungsi fisiologis hormon leptin. Penelitian ini bertujuan untuk mengetahui keragaman gen leptin berdasarkan perubahan basa pada sekuen nukleotida (Single Nucleotide Polymorphism/SNP) di gen leptin pada sapi Peranakan Ongol (PO). Sampel DNA diperoleh dari 48 ekor sapi PO di Balai Pengembangan Perbibitan Ternak Sapi Potong (BPPT-SP) Cijeungjing Jawa Barat, yang diisolasi dari sel darah putih dengan metode garam pekat. Perbanyakan DNA dengan Polymerase Chain Reaction (PCR), dilanjutkan dengan sekuensing untuk mendapatkan sekuen nukleotida. Analisis SNP dilakukan dari pensejajaran (alignment) hasil sekuensing menggunakan program Bioedit dan MEGA 5.2. Hasil penelitian menunjukkan pada gen leptin exon 2 sapi PO ditemukan satu SNP yang tidak mengubah pengodean asam amino serin pada posisi g. $1025 \mathrm{~T}>\mathrm{C} / \mathrm{S} 17 \mathrm{~S}$ dan dua SNP yang mengubah pengodean asam amino g.1047C $>$ T/R25C, yaitu Arginin menjadi sistein dan g.1048G >A/R25H yang mengubah Arginin menjadi Histidin. Pada sapi PO frekuensi alel A $(44,8 \%)$ lebih tinggi dari alel $\mathrm{C}(33,3 \%)$ dan alel $\mathrm{T}(21,9 \%)$. Terdapat enam genotip, yaitu AA $(41,7 \%)$ frekuensinya lebih tinggi dari genotipe CC (20,8\%), CT (20,8\%), CA(4,2\%), TT (10,4\%) dan TA $(2,1 \%)$. Keragaman genetik berdasarkan gen leptin pada sapi PO adalah 0,65 yang termasuk dalam kategori tinggi. Alel A adalah alel spesifik pada sapi lokal Indonesia.
\end{abstract}

Kata kunci: Leptin, Sapi Peranakan Ongole, Single Nucleotide Polymorphism

\section{ABSTRACT}

Point mutation on exon 2 of leptin gene, which changes amino acid encoding from Arginine to Cysteine, may alters the physiological function of the leptin hormone. This study aimed to identify leptin gene polymorphism of Ongole Grade (OG) cattle based on Single Nucleotide Polymorphism (SNP). The DNA sample was taken from 48 head of OG cattle at Balai Pengembangan Perbibitan Ternak Sapi Potong (BPPT SP) Cijeungjing West Java, which was isolated from white blood cell using the high salt method. Amplification of DNA was done by Polymerase Chain Reaction (PCR), followed by direct sequencing to obtain nucleotide sequence. The SNP analysis was carried out from alignment of sequencing result using Bioedit and MEGA 5.2 program. The results indicated in exon 2 leptin gene of OG cattle there was one synonymous SNPs that did not change amino acids Serine encoding on g.1025T $>\mathrm{C} / \mathrm{S} 17 \mathrm{~S}$, while two non synonymous SNP altered amino acids encoding, those were g.1047C $>\mathrm{T}$ /R25C and g.1048G $>$ A/R25H. Those mutations changed amino acids encoding from Arginine to Cysteine and Arginine to Histidine respectively. In OG cattle, the frequency of A allele (44.8\%) was higher than $\mathrm{C}$ allele $(33.3 \%)$ and $\mathrm{T}$ allele $(21.9 \%)$. Six genotypes were also identified, i.e. AA (41.7\%), CC (20.8\%), CT (20.8\%), CA(4.2\%), TT (10.4\%) and TA (2.1\%). Heterozigosity of OG cattle based on 
leptin gene was 0.65 that was a high category. The A allele was a specific allele on Indonesian local cattle.

Keywords: Leptin gene, Ongole Grade cattle, Single Nucleotide Polymorphism

\section{INTRODUCTION}

One of local cattle which is widely raised in Indonesia is Ongole Grade (OG). This cattle breed is crossbred from Ongole and Indigenous breed of Indonesian cattle. The potential of local cattle as an animal genetic resources has been well identified and explored using molecular genetic technology making them to progress rapidly. Particularly in animal breeding, this technology would support to better explore genetic potential of livestock because of its speed and accuracy. Leptin gene is one of the major genes having an economic value that can be potentially used as a genetic marker (MAS; Marker Assisted Selection) to directly select a breeding stock (Sharifzadeh and Doosti, 2010).

Leptin plays an integral role in the growth process. Leptin hormone is a product of the Leptin gene, which is one of the candidate genes contributed to body weight regulation, food intake and energy metabolism (Sainz et al., 2015; Wasim, 2015). Leptin is an adiposity signal to the brain through its targets multiple neuronal population in different hypothalamic regions. These neurons connect with other neurons in the brain forming an orchestrated circuit that also integrates other metabolic signals to control energy intake and expenditure (Sainz et al., 2015). Furthermore, Wasim (2015) stated that leptin secreted by adipocytes, which is secreted into the bloodstream and signals has dominantly a major role in the body weight regulation by maintaining a balance between food intake and expenditure of energy.

The Single Nucleotide Polymorphism (SNP) analysis is one of the several methods performed to identify genetic marker. The nucleotide sequence changed or point mutation can be found as a deletion, substitution, or insertion of one nucleotide on their sequence. The SNP is a variation in the DNA level that occurs when one nucleotide in the sequence of a gene differs from the normal in a population by at least one percent (Guerra and Yu, 2005).

The study of association genetic diversity based on SNP analysis in leptin gene with productivity showed a significant result. The study of Woronuk et al. (2012) revealed that leptin gene variation based on SNP g. 1047C $>$ T/R25C at exon 2 influences body weight and backfat depth. Kononof et al. (2017) stated that SNP R25C on exon 2 of leptin gene impacted most traits assosiated with fatness. Furthermore, Orru et al. (2011) stated that in Simental Bull, the variability of fatty acids (FA) composition in muscle fat is contributed by the non-synonymous mutations in the leptin gene, in between was R25C. The study of Kawaguchi et al. (2017) presented R25C had a significant effect on C18:0 and C14:1, and suggested that this SNP could be used as an effective marker for the improvement of Japanese Black cattle. Therefore, leptin gene polymorphism based on SNP is a potential gene as MAS on beef cattle breeding.

Hilmia (2013) stated that the Leptin gene was polymorphic on local cattle of Ciamis-West Java. There were two SNPs identified, i.e. Arg25Cys/R25C and Arg25His/R25H, and there were three alleles, $\mathrm{C}(55.5 \%), \mathrm{T}(30 \%)$, and $\mathrm{H}$ (15.5\%). A new mutation was found in g. $1048 \mathrm{G}>\mathrm{A} / \mathrm{R} 25 \mathrm{H}$ position that converted the Arginine amino acids code to Histidine. The new SNP R25H in those studies is a preliminary study to further explore other Indonesian local cattles, such as Ongole Grade (OG). This study therefore aimed to identify leptin gene polymorphism of OG cattle based on SNPs on exon 2 that changes amino acids.

\section{MATERIAL AND METHODS}

This research used DNAs of 48 OG cattle, which were extracted from white blood cell by using the high salt method (Montgomery and Sise, 1990). Quantification and quality DNA were analyzed by GenQuant spectrophotometer. DNA target of leptin gene was amplified by PCR, used flanked primer forward 5'CTCACTGCTGCGTGG TCTAC3'; reverse 3'GCACTAGGATTCCGGTC TGG5'. Each PCR reagent was prepared for $20 \mu \mathrm{l}$ volumes, mixed from: 50 ng DNA template, PCR Kit, distilled water (DW), and primer $\mathrm{F} / \mathrm{R}$.

Multiplication of DNA by PCR machine was started with initial denaturation at $95^{\circ} \mathrm{C}$ for 5 minutes, followed by 35 denaturations at $95^{\circ} \mathrm{C}$ for 1 minute, annealing at $56^{\circ} \mathrm{C}$ for 1 minute 13 
seconds, extension at $72^{\circ} \mathrm{C}$ for 1 minute, and further extension at $72^{\circ} \mathrm{C}$ for 10 minutes. PCR product of Leptin gene target was confirmed by gel agarose electrophoresis. The changes of nucleotide sequence, which was identified as a SNP, was analyzed from direct sequencing result. The sequence results and SNPs identification were detected by using Bioedit and MEGA 5.2 program. Determination of allele in this study was based on three of base nucleotide (codon) which encoding amino acids, where SNP is located. C allele is $\mathrm{CGC} / \mathrm{g} 1047 \mathrm{C}$ encoding Arginine (no mutation), $\mathrm{T}$ allele was $\mathrm{TGC} / \mathrm{g} 1047 \mathrm{C}>\mathrm{T}$ encoding Cysteine (non synonimous mutation), while A allele is $\mathrm{CAC} / \mathrm{g} 1048 \mathrm{G}>\mathrm{A}$ encoding histidine (non synonimous mutation.

\section{Data Analysis}

The frequency of alleles, genotypes, and heterozygosity of leptin gene based on SNPs were calculated with Nei (1987) formula by using POPGENE.32 program.

\section{RESULTS AND DISCUSSION}

The DNA targeted was $620 \mathrm{bp}$, which covered $1^{\text {st }}$ and $2^{\text {nd }}$ intron partially, and the whole of exon 2. It was amplified successfully as presented in Figure 1. Genetic variation on DNA level was evaluated due to the differences in the nucleotide sequence, either in the coding region or non coding region. There are several methods that can be applied to evaluate genetic differences at the nucleotide level, such as RFLP (Restricted Fragment Length Polymorphism), SSCP (Single Strength Comformation Polymorphism), and SNPs was based on nucleotide sequence. In this study, identification of SNPs on leptin gene exon 2 was based on nucleotide substitution at g. $1047 \mathrm{C}>\mathrm{T}$ or Arg25Cys (access no NCBI
EU313203.1) and g1048G $>$ A Arg25His (Hilmia, 2013). The results of align nucleotide sequence and amino acids to confirm SNPs on Leptin gene of OG cattle is presented in Figure 2.

Mutation on nucleotide sequence may occur in 5 UTR, exon, intron or 3'UTR positions. The nucleotide sequence of exon 2 in leptin gene of OG cattle was aligned with Bos indicus nucleotide sequence (access no. NCBI EU313203.1) using Bioedit and MEGA 5.2 program. The results showed that there were three SNPs on $144 \mathrm{bp}$ of exon 2. The first mutation (SNP) was found at nucleotide sequence g.1025T $>\mathrm{C}$ (access no NCBI EU313203.1), on encoded $17^{\text {th }}$ amino acid (Serine). This SNP was a base nitrogen substitution of thymine to cytosine that did not change amino acids encoding (C17C/Serin). This was called silent mutation or synonimous mutation.

Further mutations were found at g. $1047 \mathrm{C}>\mathrm{T}$ and g.1048G $>A$ in the exon 2 leptin gene nucleotide sequence (access no. NCBI EU313203.1). This position was an encoding of the $25^{\text {th }}$ amino acid (Arginine). There were two substitutions of base nitrogen, which changed amino acid encoding Arginine to Cysteine (Arg25Cys/R25C) and Arginine to Histidine (Arg25His/R25H), as shown on Figure 3. Those results correspond to Hilmia (2013) who stated that in the local cattle Ciamis, leptin gene was polymorphic, and there were two non synonymous SNPs identified, i.e. R25C/Arg25Cys and R25H/Arg25His. These mutations were non synonimous mutation (SNPns) that consequently may change leptin hormone function. Fortes et al. (2009) stated that mutation of leptin gene on SNP R25C is causative mutation that may change leptin function in the physiological processes.

The discovery of two non synonimous SNPs

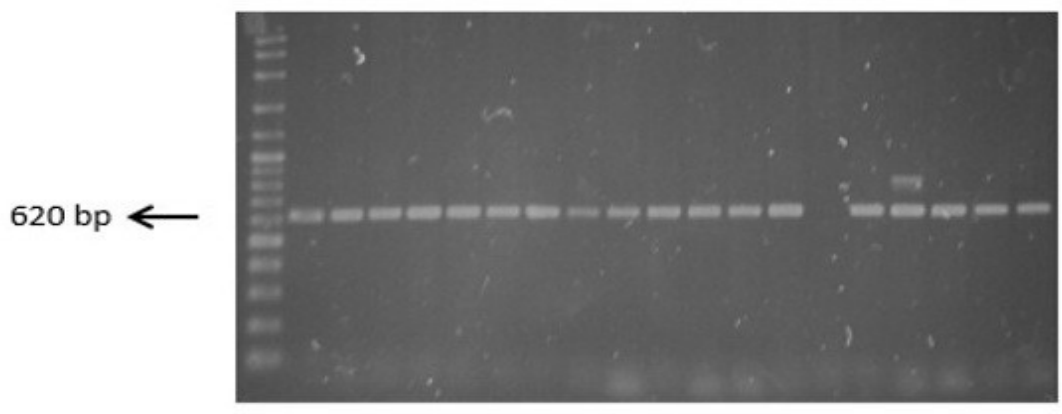

Figure 1. PCR Product of Leptin Gene 620 bp 
Bos_indicus_leptin

Allèle C

Allele $\mathrm{T}$

Allele $A$

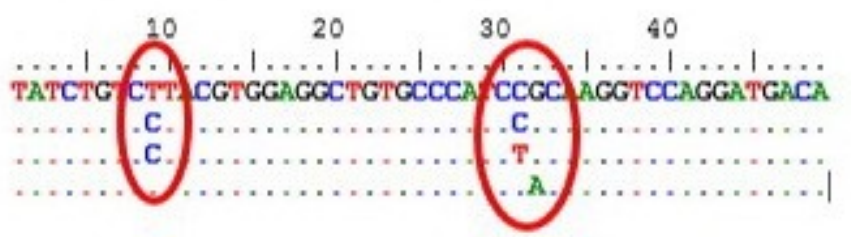

Figure 2. Alligment Result of Nucleotide Sequence on Exon 2 Leptin Gene and Allele Identification based on SNP R25C (Arg25Cys/g.1047C > T) and R25H (Arg25His/g.1048G >A)

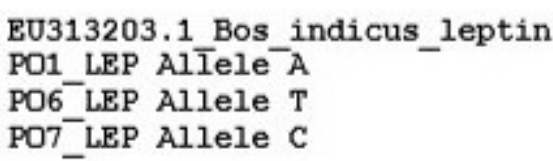

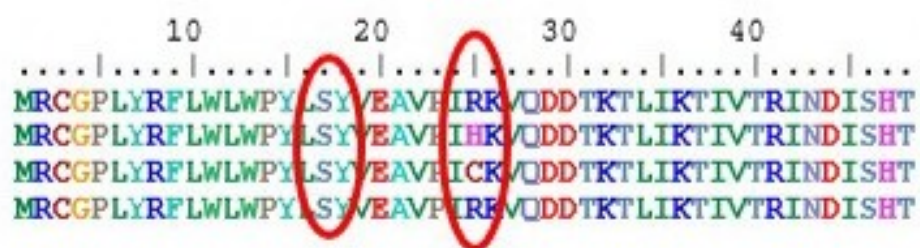

Figure 3. Alignment Result of Amino Acid on Exon 2 Leptin Gene of Ongole Grade Cattle in OG cattle in this research, which is in line with Hilmia (2013) who has found two SNPs on Ciamis local cattle, is expected to change biological function of leptin hormone in Indonesian local cattle. Buchanan et al. (2002) revealed that SNP in exon 2 is a mutation that affects the biological fuction of leptin gene. This is supported by high expression of leptin mRNA in homozygous cattle (TT), which has an allele mutation on $\mathrm{R} 25 \mathrm{C}$. This SNP may change protein molecules function, the presence of cysteine in A helix of leptin molecule may impair leptin binding to their receptor. The presence of uncoupled leptin in protein molecules can disrupt the stability of disulfide bonding. This disulfide bond is very important in biological functions. Fortes et al. (2009) stated that SNP R25C (T allele) adds extra cysteine to proteins resulting in the loss of biological functions of protein. Therefore, it can be a causative mutation.

The study of Foote et al. (2015) revealed that there was a significant assosiation between leptin concentrations with 12th-rib fat thickness, yield grade, and marbling score. Status of leptin concentrations on finishing beef cattle could be a useful physiological marker for growth and feed efficiency. Further, genetic aspect of leptin, should be considered when using leptin as physiological marker for production. Kononoff et al. (2017) stated that leptin genotype based on $\mathrm{R} 25 \mathrm{C}$ affected 12th-rib fat, intra muscular fat percentage (IMF) at 60 and $1 \mathrm{~d}$ prior to slaughter, steers homozygous for the T allele (TT) genotype had higher dry matter intake, empty body fat and $\mathrm{HCW}$. These results contribute to further explore the nucleotide sequence of leptin genes in Indonesian local cattle. This may affect leptin gene function as a regulator of feed intake, energy expenditure, fat desposition and other physiological functions.

Allele determination of leptin gene was analyzed based on two SNPs, i.e R25C (Arg25Cys / g.1047C > T) and R25H Arg25His / g.1048 G $>$ A. The SNP S17S / g.1025T $>$ C was not included in allele determination because this was a silent mutation, which did not change amino acids encodes as presented in Figure 2.

Figure 2 depicted that the $\mathrm{C}$ allele (CGC) was not mutate allele. $\mathrm{T}$ allele (TGC) was a mutated allele that converted the amino acid Arginine to Cysteine, and the A allele (CAC) was an allele that changed encoded amino acid Arginine to Histidine.

Heterozigosity, Allele and Genotype Frequency based on SNP R25C (Arg25Cys/g.1047C $>$ T) and R25H (Arg25His/g.1048G $>$ A) on OG cattle is presented in Table 1. Based on those SNPs, this study declared that the frequency of A allele (44.8\%) was higher than $\mathrm{C}$ allele (33.3\%) and $\mathrm{T}$ allele $(21.9 \%)$. Hereafter, AA genotypes $(41.7 \%)$ were higher than CC genotype (20.8\%), CT (20.8\%), CA $(4.2 \%)$, TT $(10.4 \%)$, and TA $(2.1 \%)$. The alleles frequency on this study differs from the 
Table 1. Heterozigosity, Allele and Genotype Frequency based on SNP R25C (Arg25Cys/g.1047C $>$ T) and R25H (Arg25His/g.1048G>A) on Ongol Grade Cattle

\begin{tabular}{|c|c|c|c|c|c|c|c|c|c|c|}
\hline \multirow{2}{*}{ Item } & \multicolumn{3}{|c|}{ Allele Frequency } & \multicolumn{6}{|c|}{ Genotype Frequency } & \multirow[t]{2}{*}{$\mathrm{He}$} \\
\hline & $\mathrm{C}$ & $\mathrm{T}$ & A & $\mathrm{CC}$ & $\mathrm{CT}$ & $\mathrm{CA}$ & TT & TA & AA & \\
\hline $\mathrm{N}$ & 32 & 21 & 43 & 10 & 10 & 2 & 5 & 1 & 20 & \\
\hline Value & 0.333 & 0.219 & 0.448 & 0.208 & 0.208 & 0.042 & 0.104 & 0.021 & 0.417 & 0.65 \\
\hline
\end{tabular}

$\mathrm{N}=$ Number of sample; $\mathrm{He}=$ Expected Heterogosity

study of Hilmia (2013) on 78 head of Ciamis local cattle who presented there were three alleles, C allele as the highest frequency (55.5\%), compared to $\mathrm{T}(30 \%)$ and $\mathrm{H} / \mathrm{A}$ allele $(15 \%)$.

The results of this study and Hilmia (2013) differ from other studies on Bos taurus and Bos indicus cattle, because SNP R25H was not found on those breed (access no. NCBI. U50365.1 and EU313203.1). Lagognigro et al. (2003) revealed that in 169 Charolais and FH bulls, the frequency of $\mathrm{C}$ allele was $65 \%$, while $\mathrm{T}$ allele was $35 \%$. The study of Leifers et al. (2005) conducted in $613 \mathrm{FH}$ showed that the $\mathrm{C}$ allele frequency was higher (65\%) than T (R25C) allele (35\%). The study of Sharifzadeh and Doosti, (2010) using PCR-RFLP with Sau3AI enzyme in Iranian Holstein cows revealed that there were three genotypes on leptin gene, i.e. $60.71 \% \mathrm{AA}, 37.5 \% \mathrm{AB}$ and $1.79 \% \mathrm{BB}$. Further, in the Nelore cattle (Bos indicus), T allele had low frequency (19\%) because no individual with TT genotype (Fortes et al., 2009). It is in contrast with Buchanan et al. (2002) who stated that British cattle (Angus and Hereford) had higher $\mathrm{T}$ than $\mathrm{C}$ allele, while in Continental cattle (Simental and Charolais) the frequency of $\mathrm{C}$ was higher than $\mathrm{T}$ allele. In 60 Angus cattle and 22 Hereford cattle, T (R25C) alleles were found with frequencies of $58 \%$ and $55 \%$, respectively. Furthermore, Kaygisiz et al. (2011) revealed that there were mutation on leptin gen in Turkey cattle. The frequencies of $\mathrm{T}$ and $\mathrm{C}$ allele were $0.54 \pm 0.06$ and $0.46 \pm 0.06$ for East Anatolian Red cattle, and $0.48 \pm 0.05$ and $0.52 \pm 0.05$ for Anatolian Black.

Genetic diversity of OG cattle based on non synonimous SNP R25C and R25H was 0.65 . It was defined as a high category. This genetic condition occurred allegedly because BPPT-SP Cijeungjing as a breeding center of local cattle in West Java obtained the breeding stock of OG cattle from several area of OG cattle sources.

\section{CONCLUSION}

This study found three SNPs on exon 2 leptin gene of Ongole Grade (OG) cattle one synonimous mutation SNP g. $1025 \mathrm{~T}>\mathrm{C} / \mathrm{S} 17 \mathrm{~S}$, and two non synonimous mutations g.1047C $>\mathrm{T} / \mathrm{R} 25 \mathrm{C}$ and g.1048G $>\mathrm{A} / \mathrm{R} 25 \mathrm{H}$. In $\mathrm{OG}$ cattle, the frequency of A allele (44.8\%) was higher than C allele $(33.3 \%)$ and $\mathrm{T}$ allele $(21.9 \%)$. The frequency of AA genotype (41.7\%) was higher than CC genotype $(20.8 \%)$, CT $(20.8 \%), \mathrm{CH}$ $(4.2 \%)$, TT (10.4\%), and TH (2.1\%). Heterozigosity of OG cattle based on these SNP was 0.65 , which was a high category. The A allele is a spesific allele in Indonesian local cattle.

\section{ACKNOWLEDGMENTS}

The authors would like to thank the Directorate of Research and Community Service of Universitas Padjadjaran which has funded this research in the Fundamental Research Scheme (RFU), Contract number 855/UN6.3.1/PL/2017.

\section{REFERENCES}

Buchanan, F.C, C.J. Fitzsimmons, A.G, Van T.D. Thue, D.C. Winkelman Sim, and S.M. Schmutz. 2002. Association of a missense mutation in the bovine leptin gene with carcass fat content and leptin mRNA levels. Genet. Sel. Evol. 34:105-116.

Guerera, R. and Z. Yu. 2017. Single Nucleotide Polymorphism and Their Aplications. In: Computational and Statistical Approaches to Genomics. (W. Zhang, and I. Shmulevich eds). Springer Nature. P.311347

Foote, A.P., K.E.Hales, L.A. Kuehn, D.H. Keisler, 
D.A. King, S.D. Shackelford, T.L. Wheeler and H.C. Freetly. 2015. Relationship of leptin concentrations with feed intake, growth, and efficiency in finishing beef steers. J. Anim. Sci. 93:4401-4407

Fortes, M.R.S., R.A. Curi, L.A.L. Chardulo, A.C. Silveira, M.E.O.D. Assumpção, J.A. Visintin and H.N. de Oliveira. 2009. Bovine gene polymorphisms related to fat deposition and meat tenderness. Genet and Mol Biol. 32(1):75-82.

Hilmia, N., R.R. Noor, C. Sumatri, R. Priyanto and E. Gurnadi. 2013. Karakterisasi Fenotipe dan Potensi Genetik Serta Hubungannya Dengan Produktivitas Dan Kualitas Daging Sapi Lokal Di Ciamis Jawa Barat. Dissertation. Institut Pertanian Bogor. Bogor

Kawaguchi, F., K. Okura, K. Oyama, H. Mannen and S. Sasazaki. 2017. Identification of leptin gene polymorphisms associated with carcass traits and fatty acid composition in Japanese Black cattle. J. Anim. Sci. 88(3):433-438.

Kaygisiz, A., C. Bengi and S. Cilek. 2011. Investigation of leptin gene polymorphisms in East Anatolian Red Anatolian and Black cattle and determination of genetic distance from Brown Swiss Cattle. J. Anim. Plant. Sci. 21:121-125.

Kononoff, P.J, P.J. Defoor, M.J. Engler, J.F. Gleghorn, R.S. Swingle, S.T. James and F.L.S. Marquess. 2017. Impacts of a leptin SNP on growth performance and carcass characters in finishing steers studied over time. J. Anim. Sci. 95(1):194-200.

Liefers, S.C., R.F. Veerkamp, M.F.W. Te Pas, C. Delavaud, Y. Chilliard, M. Platje, and T.
Van der Lende. 2005. Leptin promoter mutations affect leptin levels and performance traits in dairy cows. Anim. Genet. 36:111-118.

Lagonigro, R., P. Wiener, F. Pilla, J.A. Woolliams and J.L. Williams. 2003. A new mutation in the coding region of the bovine leptin gene associated with feed intake. Anim. Genet. 34:371-374.

Montgomery, G.W. and J.A. Sise. 1990. Extraction of DNA From sheep white blood cells. Agr. Res. 33:437-441.

Nei, M. 1987. Molecular Evolutionary Genetics. New York (US): Columbia University Press.

Orrù, L., G.F. Cifuni, E. Piasentier, M. Corazzin, S. Bovolenta and B. Moioli. 2011. Association analyses of single nucleotide polymorphisms in the LEP and SCD1 genes on the fatty acid profile of muscle fat in Simmental bulls. Meat Sci. 87:344-348.

Sáinz, N, J. Barrenetxe, M. J. Moreno-Aliaga and J.A. Martínez. 2015. Leptin resistance and diet-induced obesity: central and peripheral actions of leptin. J. Metab. Clin and exp. 64: $35-46$

Sharifzadeh, A. and A. Doosti. 2010. Genetic polymorphism at the leptin gene in iranian Holstein cattle by PCR-RFLP. African. J. Microbiol Res. 4(12):1343-1345.

Wasim, M. 2015. Role of Leptin in Obesity. J. Obes. Weight. Loss. Ther. 5(258):1-3.

Woronuk, G.N., F.L. Marquess, S.T. James, J. Palmer, T . Berryere, H. Deobald., S. Howie and P.J. Kononoff. 2012. Association of leptin genotypes with beef cattle characteristics. Anim. Genet. 43(5):608-610 